Original Article

\title{
RP-HPLC AND CHEMOMETRIC METHODS FOR THE DETERMINATION OF TWO ANTI- DIABETIC MIXTURES; METFORMIN HYDROCHLORIDE-CANAGLIFLOZIN AND METFORMIN HYDROCHLORIDE-GLICLAZIDE IN THEIR PHARMACEUTICAL FORMULATION
}

\author{
MALAK Y. AL-BATHISH' ${ }^{1}$, AZZA A. GAZY², MARWA K. EL-JAMAL ${ }^{2}$ \\ ${ }^{1,2}$ Department of Pharmaceutical Technology, Faculty of Pharmacy, Beirut Arab University, Beirut, Lebanon \\ Email: malak.albathish@gmail.com
}

Received: 20 Aug 2019, Revised and Accepted: 12 Dec 2019

\section{ABSTRACT}

Objective: To develop and validate novel more sensitive analytical methods for the concurrent quantification of metformin-canagliflozin and metformin-gliclazide in their bulk forms and in their pharmaceutical preparations.

Methods: Two methods were developed based on several chemometric assisted spectrophotometric methods and a Reversed-Phase High-Performance Liquid Chromatography (RP-HPLC). The first method applies different spectrophotometric chemometric assisted methods, including ratio difference, derivative ratio and extended ratio subtraction method, while the second method describes a RP-HPLC separation of metformin hydrochloridecanagliflozin and metformin hydrochloride-gliclazide binary mixtures using a C18 column with a mobile phase consisting of acetonitrile: potassium dihydrogen phosphate (adjusted to $\mathrm{pH} 3$ ) with sodium lauryl sulphate as additive in the ratio of 30:70 (\%v/v) in isocratic elution mode at $1 \mathrm{ml} / \mathrm{min}$.

Results: The proposed methods were able to quantify each of the studied drugs in their binary mixtures with high percentage recoveries in both methods. The spectrophotometric methods were able to quantify each of metformin, canagliflozin and gliclazide in the ranges of $2.0-20.0 \mu \mathrm{g} / \mathrm{ml}, 1.5-$ $40.0 \mu \mathrm{g} / \mathrm{ml}$ and $2.0-30.0 \mu \mathrm{g} / \mathrm{ml}$, respectively. The RP-HPLC method produced well-resolved peaks at a retention time of $3.92,6.92$ and $9.10 \mathrm{~min}$ in the concentration ranges of $50.0-300.0 \mu \mathrm{g} / \mathrm{ml}, 5.0-50.0 \mu \mathrm{g} / \mathrm{ml}$ and $10.0-100.0 \mu \mathrm{g} / \mathrm{ml}$ for metformin, canagliflozin and gliclazide, respectively. The proposed methods were optimized and validated in accordance to the International Conference of Harmonisation (ICH) guidelines in terms of linearity, LOD, LOQ, precision and accuracy.

Conclusion: The developed methods were found to be sensitive and reproducible methods for the simultaneous determination of anti-diabetic binary mixtures; metformin hydrochloride-canagliflozin and metformin hydrochloride-gliclazide. And thus were successfully employed for the quality control analysis of the pharmaceutical formulations of the studied binary mixtures.

Keywords: Binary mixtures, Metformin-Canagliflozin, Metformin-Gliclazide, Spectrophotometric chemometric assisted methods, RP-HPLC

(C) 2020 The Authors. Published by Innovare Academic Sciences Pvt Ltd. This is an open-access article under the CC BY license (http://creativecommons.org/licenses/by/4.0/) DOI: http://dx.doi.org/10.22159/ijpps.2020v12i2.35415. Journal homepage: https://innovareacademics.in/journals/index.php/ijpps

\section{INTRODUCTION}

Diabetes is a lifelong progressive disease characterized by high levels of blood glucose [1]. Currently, metformin is being used as first-line therapy in the treatment of diabetes mellitus type 2 . However, for most patients, glycemic control is not sufficiently established by this monotherapy, leading to the requirement for combination therapy. Metformin hydrochloride-Canagliflozin is a recently introduced co-formulation in the market whereas metformin hydrochloride-gliclazide is one of the most used coformulation in the current practice.

Metformin (MTF) is official in both the British Pharmacopeia (BP) [2] and United State Pharmacopeia (USP) [3], gliclazide (GLIC) is official in the BP, whereas Canagliflozin (CANA) is still a novel drug in the market, and no official method is yet available in any pharmacopoeia.

Literature survey has revealed that each of the metformin hydrochloride, canagliflozin and gliclazide were determined individually as a single component in bulk, pharmaceutical formulations and biological fluids by several analytical methods. Metformin hydrochloride has been determined simultaneously with canagliflozin using RP-HPLC [4-7] and spectrophotometry [8]. In presence of gliclazide, metformin hydrochloride has been determined by High Performance Thin Layer Chromatography (HPTLC) [9, 10], Liquid Chromatography-Mass Spectrometry (LCMS) [11, 12], spectrophotometric methods [13-17], and HPLC with Ultra-violet (UV) detection [18-26].
(A)<smiles>CN(C)C(=N)NC(=N)N</smiles>

(B)<smiles>Cc1ccc(C2OC(CO)C(C)CC2c2cccc(-c3ccc(F)cc3)c2)cc1</smiles>

(C)<smiles>Cc1ccc(S(=O)(=O)NC(=O)NN2CC3CCCC3C2)cc1</smiles>

Fig. 1: Structures of (A) Metformin Hydrochloride, (B) Canagliflozin, (C) Gliclazide

Spectrophotometric methods present a good option in the analysis of multicomponent pharmaceutical mixtures based on the availability, simplicity and low cost. Classical UV spectral measurement use is often limited due to the overlapping of spectral peaks unless prior separation and extraction are employed. Several UV spectrophotometric chemometric methods are used in the 
simultaneous analysis for resolving mixtures based on mathematical processing and manipulations of the absorption spectra [27-34], offering sometimes an alternative to chromatographic methods.

This work aims to evolve new, yet more sensitive methods for concurrent quantification of MTF-CANA and MTF-GLIC in their bulk forms and in their pharmaceutical preparations. The idea for the comparative study using two different techniques has emerged from the need to find the most suitable analytical method in short time to be applicable in quality control labs giving the analyst the choice of the preferable detector based on its availability. The methods are based on several chemometric methods [27] including ratio difference, derivative ratio, and extended ratio subtraction methods, also a RP-HPLC. Methods have been developed and followed by full validation for each method.

\section{MATERIALS AND METHODS}

\section{Chemicals and materials}

Metformin hydrochloride was certified to contain 99.7\% (Merck Sante, France), Canagliflozin was certified to contain $99.8 \%$ (Janssen Cilag, USA), and Gliclazide was certified to contain 99.3\% (Servier, France).

Vokanamet ${ }^{\circledR}$ tablets (Janssen Cilag, USA), labelled to contain $850 \mathrm{mg}$ metformin hydrochloride and $50 \mathrm{mg}$ canagliflozin. Orbizide $\mathrm{M}$ Forte $^{\circledR}$ tablets (Pharmaline, Lebanon) labelled to contain $500 \mathrm{mg}$ metformin hydrochloride and $40 \mathrm{mg}$ gliclazide.

All chemicals and solvents used were of HPLC grade; Methanol (SIGMA-ALDRICH, CHROMASOLV ${ }^{\circledR}$ FOR HPLC), acetonitrile (SIGMAALDRICH CHROMASOLV ${ }^{\circledR}$ FOR HPLC $\left.>99.9 \%\right), \quad \mathrm{KH}_{2} \mathrm{PO}_{4}$ (Merck KGaA), deionized water was produced in-house.

\section{Instrumentation}

Jasco V-730 double beam UV-Vis Spectrophotometer interfaced to a computer programmed with Jasco Spectra Manager software was used for spectrophotometric measurements, spectral acquisition and elaboration. A pair of $1 \mathrm{~cm}$ quartz cells were used to measure the absorption spectra.

The RP-HPLC separation was performed on an HPLC system; Jasco PU-2089 series (Japan) equipped with quaternary pump, diode array detector, and a manual injector which uses a Rheodyne port sample injection valve fitted with $20 \mu \mathrm{l}$ sample loop. Liquid separations are performed on Lichrospher $100 \mathrm{RP} \mathrm{C}_{18}$ analytical column ( $250 \mathrm{~mm} \times 4.6 \mathrm{~mm} \times 5 \mu \mathrm{m})$. A Glassco diaphragm Vacuuum pump was used to degas and filter the mobile phase by passing through $0.5 \mu \mathrm{m}$ pore size membrane filter at a pumping speed of 30 L/min. A $0.2 \mu \mathrm{m}$ Minisart SRP 15 (Sartorius Stedim) syringe driven disposable filters was used to filter the samples.

\section{Preparation of standard stock solutions}

Stock solutions of MTF, CANA and GLIC standards having the concentrations of $1000 \mu \mathrm{g} / \mathrm{ml}, 1000 \mu \mathrm{g} / \mathrm{ml}$, and $600 \mu \mathrm{g} / \mathrm{ml}$, respectively, were prepared using methanol as a solvent.

\section{Chemometric assisted spectrophotometric methods}

\section{Preparation of working standard solutions}

Aliquots of the standard stock solutions of each drug were separately diluted with methanol to obtain working standard solutions having the concentrations of $200 \mu \mathrm{g} / \mathrm{ml}$ for MTF, 100 $\mu \mathrm{g} / \mathrm{ml}$ for CANA and $60 \mu \mathrm{g} / \mathrm{ml}$ for GLIC.

\section{Calibration graphs}

Calibration graphs were prepared from these working standard solutions by diluting with methanol to achieve the concentration range of $2-20 \mu \mathrm{g} / \mathrm{ml}$ for MTF, $1.5-40 \mu \mathrm{g} / \mathrm{ml}$ for CANA and $2-30$ $\mu \mathrm{g} / \mathrm{ml}$ for GLIC. The absorption spectra were recorded at $1-\mathrm{nm}$ interval in the range of $200-300 \mathrm{~nm}$ for GLIC and $200-400 \mathrm{~nm}$ for MTF and CANA, against methanol as blank.

\section{Synthetic mixtures}

Aliquots of the working standard solutions of MTF and CANA or MTF and GLIC were transferred into a series of $10-\mathrm{ml}$ volumetric flasks and completed to volume with methanol to give synthetic mixtures containing $20: 5 \mu \mathrm{g} / \mathrm{ml}$ and $15: 2.5 \mu \mathrm{g} / \mathrm{ml}$, respectively. The absorption spectrum for each mixture was recorded at 1-nm interval in the range of $200-400 \mathrm{~nm}$ against methanol as blank and then analysed by the developed method to assay the quantity of both MTF-CANA, or MTF-GLIC in the synthetic mixtures.

\section{RP-HPLC method}

\section{Chromatographic conditions}

The chromatographic analysis was performed with isocratic elution using $\mathrm{C}_{18}$ column at a detection wavelength of $229 \mathrm{~nm}$. The mobile phase used for the chromatographic separation was prepared by adding HPLC grade acetonitrile to the aqueous phase in the ratio of $30: 70 \% \mathrm{v} / \mathrm{v}$. The mobile phase was pumped through the column at a flow rate of $1 \mathrm{ml} / \mathrm{min}$ and injection volume of $20 \mu \mathrm{l}$. Separation was carried out at ambient temperature.

The aqueous phase was prepared by weighing $1.36 \mathrm{~g}$ of potassium dihydrogen phosphate $\left(\mathrm{KH}_{2} \mathrm{PO}_{4}\right)$ and $2.88 \mathrm{~g}$ of sodium lauryl sulphate and dissolving them in 1 L HPLC grade water, then adjusting its $\mathrm{pH}$ to a value of 3 with orthophosphoric acid.

The mobile phase was filtered and degassed for 30 min using an ultrasonic sonicator.

\section{Calibration graphs}

Calibration graphs were prepared from the standard stock solutions by diluting with methanol to achieve the concentration range of 50$300 \mu \mathrm{g} / \mathrm{ml}$ for MTF, $5-50 \mu \mathrm{g} / \mathrm{ml}$ for CANA and $10-100 \mu \mathrm{g} / \mathrm{ml}$ for GLIC. The above solutions were filtered and $20 \mu \mathrm{l}$ portion of these solutions were injected and chromatographed. The standard calibration graphs were prepared by plotting the peak area values of each drug against the corresponding concentrations.

\section{Synthetic mixtures}

Aliquots of standard stock solutions of MTF, CANA or GLIC were transferred into a series of $10-\mathrm{ml}$ volumetric flasks and completed to volume with methanol to give synthetic mixtures in the ratios stated in table 7 . The above solutions were filtered and $20 \mu \mathrm{l}$ portion of these solutions were injected in triplicates on three different days and chromatographed. The peak areas for each drug were used to acquire the corresponding concentration by referring to its calibration graph.

\section{Pharmaceutical application}

Ten tablets of Orbizide ${ }^{\circledR}$ or Vokanamet ${ }^{\circledR}$ were accurately weighed and finely powdered. Powder amount equivalent to one tablet of each, was accurately weighed, transferred to a $100-\mathrm{mL}$ volumetric flask and diluted to volume with HPLC grade methanol. The obtained solutions were then filtered using Whatmann No. 41 filter paper. An appropriate volume of these solutions was transferred to $10-\mathrm{ml}$ volumetric flask, diluted to the mark with the same solvent.

The absorption spectra of the obtained solutions were recorded at 1$\mathrm{nm}$ interval in the range of $200-400 \mathrm{~nm}$ against methanol as a blank and then analyzed by the developed chemometric assisted spectrophotometric methods to assay the quantity of each drug in their co-formulated pharmaceutical tablets.

In RP-HPLC method, the solutions were filtered and $20 \mu \mathrm{l}$ portion of these solutions were injected in five replicates and chromatographed. The peak areas for each drug were used to acquire the corresponding concentration by referring to its calibration graph.

\section{Method validation}

Under the optimized experimental conditions, the developed methods were validated according to the procedures described in ICH guidelines for the following parameters: Linearity, limit of detection (LOD), limit of quantitation (LOQ), precision and accuracy [35].

Linearity, concentration range, limit of detection and limit of quantitation

Linearity was determined in the concentration range of $2-20 \mu \mathrm{g} / \mathrm{ml}$ for MTF, $1.5-40 \mu \mathrm{g} / \mathrm{ml}$ for CANA and $2-30 \mu \mathrm{g} / \mathrm{ml}$ for GLIC for the chemometric assisted spectrophotometric methods, and 50-300 
$\mu \mathrm{g} / \mathrm{ml}$ for MTF, 5-50 $\mu \mathrm{g} / \mathrm{ml}$ for CANA and 10-100 $\mu \mathrm{g} / \mathrm{ml}$ for GLIC for the RP-HPLC method. The amount of MTF, CANA and GLIC present in the sample was computed from the corresponding calibration curve.

LOD and LOQ were calculated according to the ICH guidelines by using the following formula [35]:

$$
\mathrm{LOD}=\frac{3.3 \mathrm{~S}_{\mathrm{y} / \mathrm{x}}}{\mathrm{b}} \text { and } \mathrm{LOQ}=\frac{10 \mathrm{~S}_{\mathrm{y} / \mathrm{x}}}{\mathrm{b}}
$$

Where " $\mathrm{S}_{\mathrm{y} / \mathrm{x}}$ " is the standard deviation of the regression line/residuals and " $b$ " is the slope of the calibration curve.

\section{Accuracy and precision}

In order to assess the accuracy and precision of the proposed methods, standard solutions containing MTF, GLIC or CANA and synthetic mixtures with different ratios of MTF-CANA and MTF-GLIC were analysed. The precision of the proposed methods was assessed by intra-day and inter-day variation studies using three concentrations of each for five times. During intra-day studies, five sample solutions of each concentration were analysed on the same day whereas inter-day studies were determined by analysing five sample solutions of each concentration for three consecutive days. The accuracy of the proposed methods was assessed by analysing synthetic mixtures with different ratios. Afterwards, the mean percentage recovery and percentage relative standard deviation were calculated.

\section{RESULTS AND DISCUSSION}

\section{Chemometric assisted spectrophotometric methods}

The spectral overlapping between the absorption spectra of MTF and CANA (fig. 2) or MTF and GLIC (fig. 3) exhibit significant interference imposed by each drug while determining the other which limits the use of conventional UV spectrophotometry for their simultaneous determination. Therefore, simultaneous determination of these drugs in binary mixture or in co-formulated pharmaceutical formulations requires mathematical manipulation of the absorption data to omit the interference. Accordingly, three simple spectrophotometric methods; namely ratio difference, derivative ratio, and extended ratio subtraction methods were developed for the determination of MTF-CANA and MTF-GLIC in their binary mixtures.

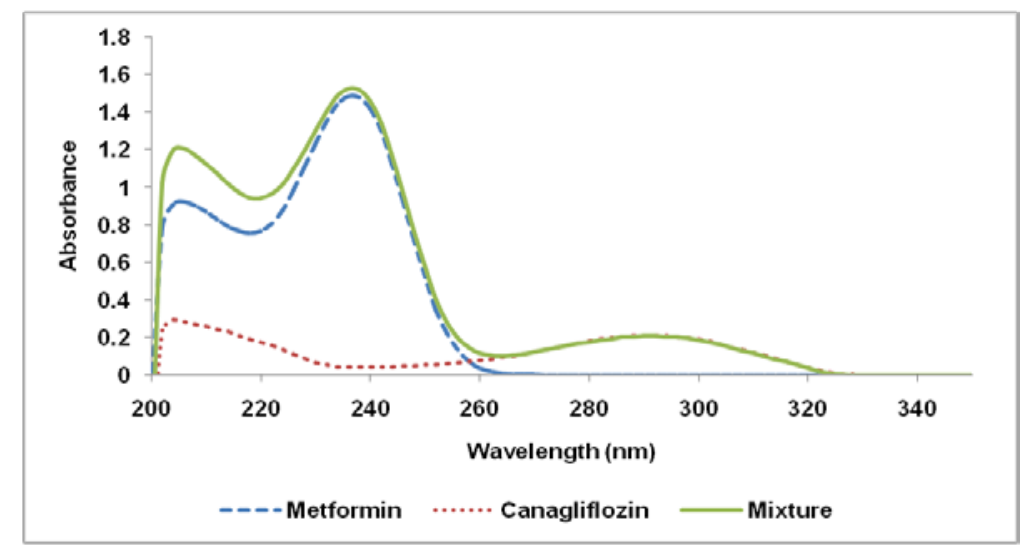

Fig. 2: Overlain absorption spectra of MTF $(16 \mu \mathrm{g} / \mathrm{ml})$, CANA $(5 \mu \mathrm{g} / \mathrm{ml})$ and their binary mixture

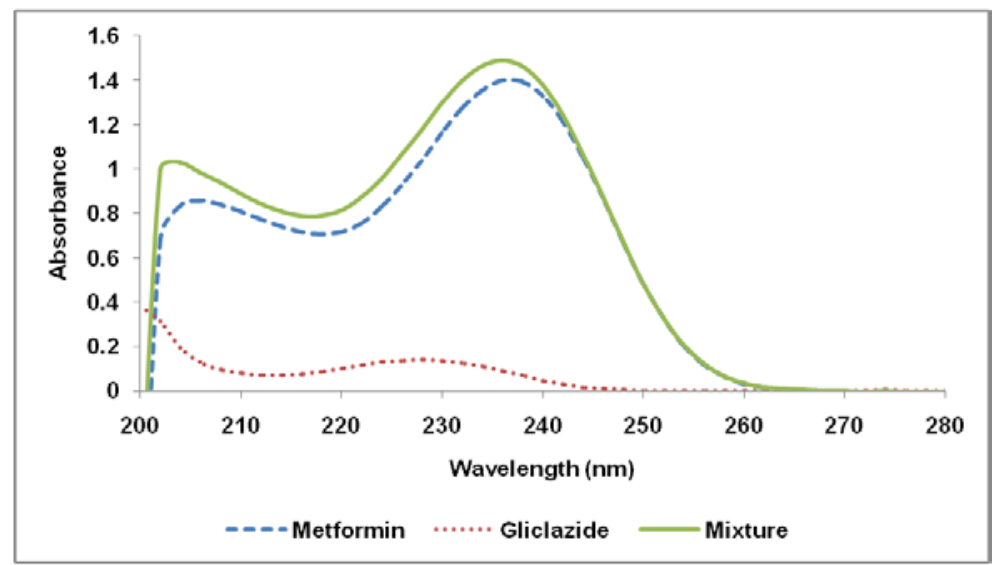

Fig. 3: Overlain absorption spectra of MTF $(15 \mu \mathrm{g} / \mathrm{ml})$, GLIC $(3.5 \mu \mathrm{g} / \mathrm{ml})$ and their binary mixture

\section{Ratio difference $(\Delta \mathrm{P})$}

As shown in fig. 2 and fig. 3, the absorption spectra of the binary mixtures composed of MTF-CANA or MTF-GLIC show high degree of overlap. So, to overcome this mutual interference, the absorbance ratio; a one-step correction method was adopted.

For method optimization, two factors were considered: the effect of divisor concentration for each drug and the choice of the wavelength. Selection was based on minimum noise, maximum sensitivity, high accuracy and precision. When the concentration of the divisor was varied, the ratio spectra proportionally varied with no change in the position of the peaks and troughs [27, 29].

MTF was determined in MTF-CANA binary mixture, where the recorded spectra of standard MTF solutions and that of its mixtures with CANA were divided by the absorption spectrum of CANA having the concentration of $2 \mu \mathrm{g} / \mathrm{ml}$. The ratio spectra of different MTF standard solutions were obtained. The peak to trough amplitudes between 233-211 nm on the established ratio spectra were proportional to MTF concentration. Consequently, the regression equation was derived (fig. 4). 


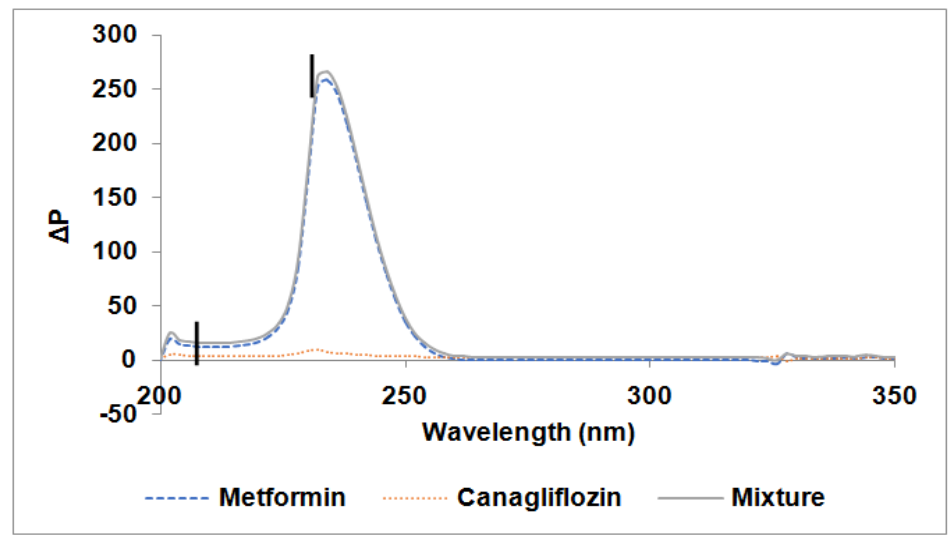

Fig. 4: Ratio spectra of MTF $(16 \mu \mathrm{g} / \mathrm{ml})$, CANA $(5 \mu \mathrm{g} / \mathrm{ml})$ and their binary mixture where the divisor is CANA $(2 \mu \mathrm{g} / \mathrm{ml})$

CANA was determined in MTF-CANA binary mixture, where the recorded spectra of standard CANA solutions and that of its mixtures with MTF were divided by the absorption spectrum of MTF having the concentration of $18 \mu \mathrm{g} / \mathrm{ml}$. The ratio spectra of different CANA standard solutions were obtained. The peak to trough amplitudes between 278-295 $\mathrm{nm}$ on the established ratio spectra were proportional to CANA concentration. Consequently, the regression equation was derived (fig. 5).

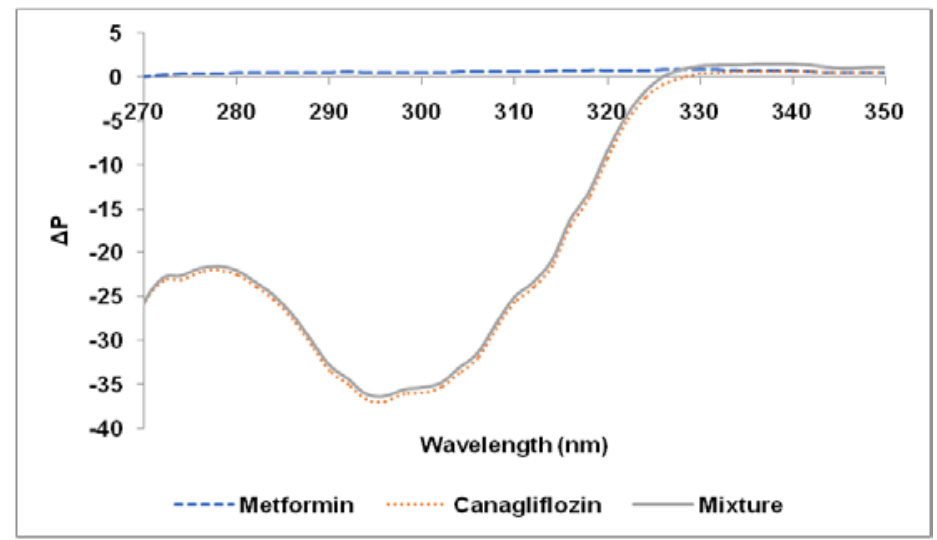

Fig. 5: Ratio spectra of MTF $(16 \mu \mathrm{g} / \mathrm{ml})$, CANA $(5 \mu \mathrm{g} / \mathrm{ml})$ and their binary mixture where the divisor is MTF $(18 \mu \mathrm{g} / \mathrm{ml})$

MTF was determined in MTF-GLIC binary mixture, where the recorded spectra of standard MTF solutions and that of its mixtures with GLIC were divided by the absorption spectrum of GLIC having the concentration of $4.5 \mu \mathrm{g} / \mathrm{ml}$. The ratio spectra of different MTF standard solutions were obtained. The peak to trough amplitudes between 248-222 $\mathrm{nm}$ on the established ratio spectra were proportional to MTF concentration. Consequently, the regression equation was derived (fig. 6).

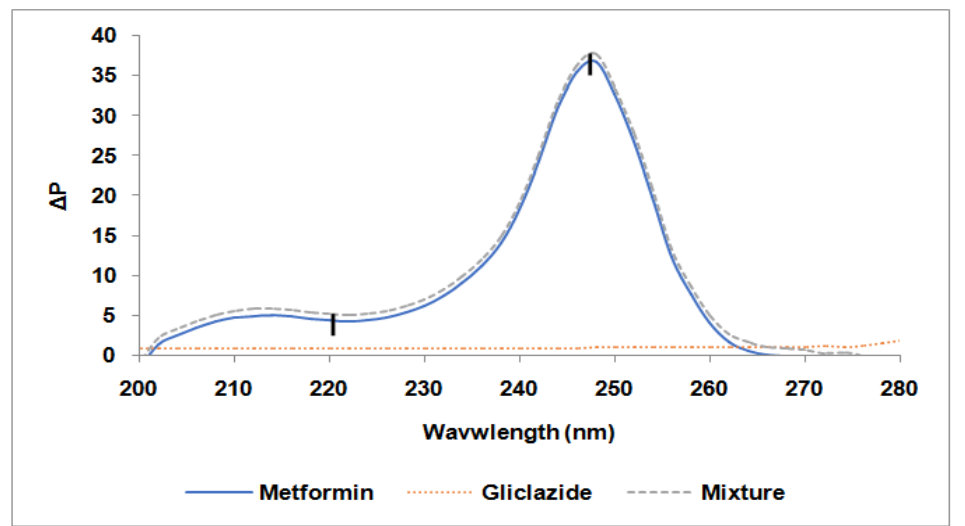

Fig. 6: Ratio spectra of MTF $(15 \mu \mathrm{g} / \mathrm{ml})$, GLIC $(3.5 \mu \mathrm{g} / \mathrm{ml})$ and their binary mixture where the divisor is GLIC $(4.5 \mu \mathrm{g} / \mathrm{ml})$

GLIC was determined in MTF-GLIC binary mixture, where the recorded spectra of standard GLIC solutions and that of its mixtures with MTF were divided by the absorption spectrum of MTF having the concentration of $18 \mu \mathrm{g} / \mathrm{ml}$. The ratio spectra of different GLIC standard solutions were obtained. The peak to trough amplitudes between 223-248 $\mathrm{nm}$ on the established ratio spectra were proportional to GLIC concentration. Consequently, the regression equation was derived (fig. 7). 


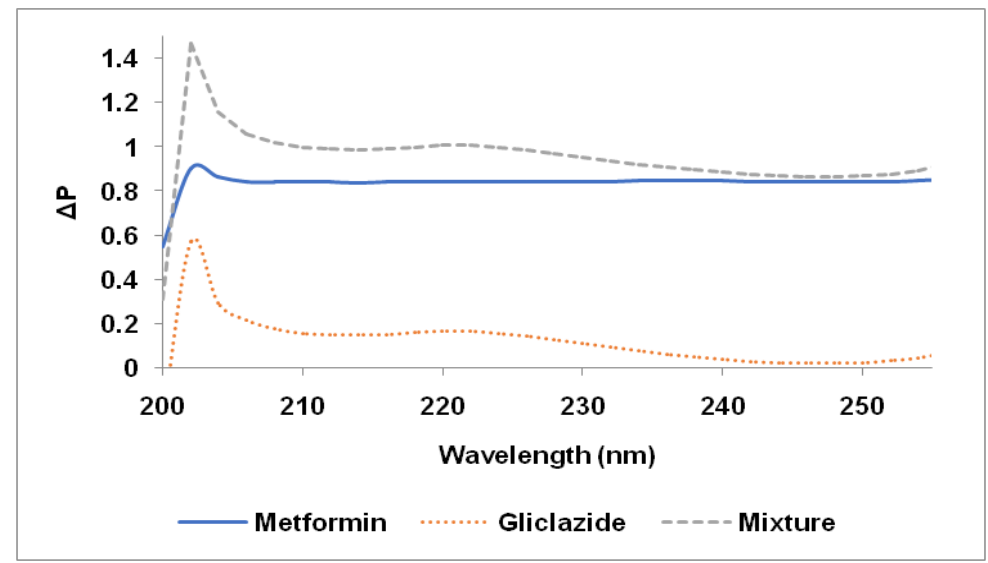

Fig. 7: Ratio spectra of MTF $(15 \mu \mathrm{g} / \mathrm{ml})$, GLIC $(3.5 \mu \mathrm{g} / \mathrm{ml})$ and their binary mixture where the divisor is MTF $(18 \mu \mathrm{g} / \mathrm{ml})$

\section{First derivative ratio $D_{1} R$}

In this method, two parameters were studied and optimized to obtain good selectivity and high sensitivity: wavelength interval $(\Delta \lambda)$ and divisor concentration [27, 31-33].

The influence of $\Delta \lambda$ was investigated to obtain the optimum wavelength intervals in terms of maximum resolution and sensitivity whereby the $\Delta \lambda$ value affects the shape and the position of the peaks to be analysed as well as the zero-crossing point of the other component in the mixture. The $\mathrm{D}_{1}$ curves were traced at $8 \mathrm{~nm}$ interval for MTF-CANA and at $6 \mathrm{~nm}$ for MTF-GLIC, where other $\Delta \lambda$ values gave poor resolution.

The concentration of MTF was determined at $244 \mathrm{~nm}$ for both binary mixtures in the corresponding $\mathrm{D}_{1}$ curves obtained from the ratio spectra where the divisors were CANA $(2 \mu \mathrm{g} / \mathrm{ml})$ and GLIC $(4.5 \mu \mathrm{g} / \mathrm{ml})$, respectively. The concentration in the mixture was derived from the calibration curve of the $\mathrm{D}_{1} \mathrm{R}$ of standard MTF (fig. 8 and fig. 9).

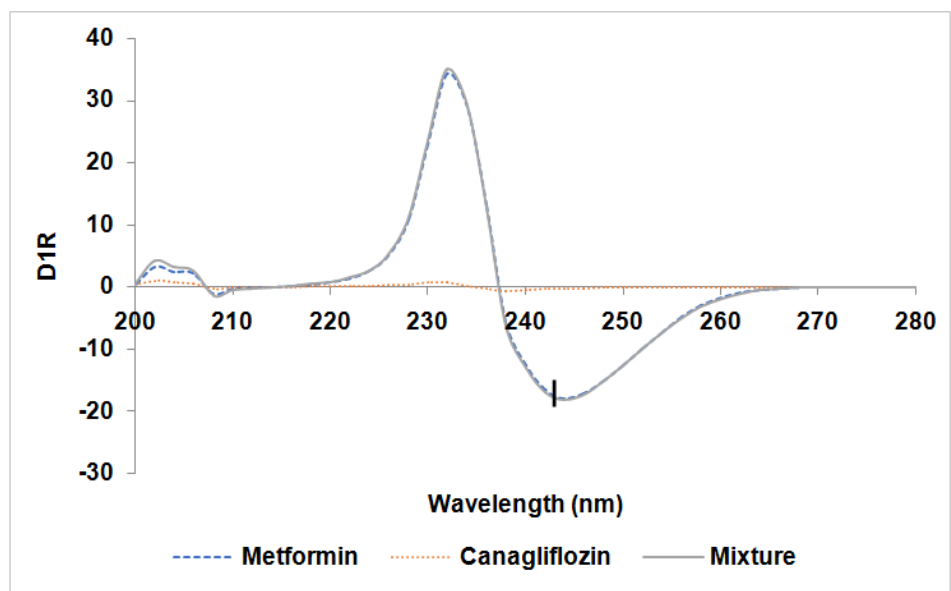

Fig. 8: $D_{1}$ of the ratio spectra of MTF $(16 \mu \mathrm{g} / \mathrm{ml})$, CANA $(5 \mu \mathrm{g} / \mathrm{ml})$ and their binary mixture where the divisor is CANA $(2 \mu \mathrm{g} / \mathrm{ml})$

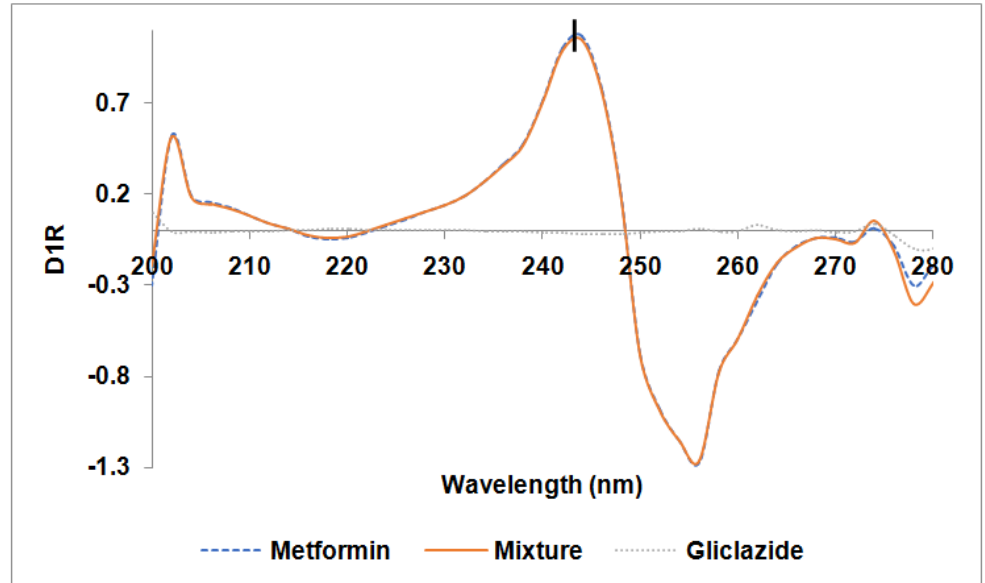

Fig. 9: $\mathrm{D}_{1}$ of the ratio spectra of MTF $(15 \mu \mathrm{g} / \mathrm{ml})$, GLIC $(3.5 \mu \mathrm{g} / \mathrm{ml})$ and their binary mixture where the divisor is GLIC (4.5 $\left.\mu \mathrm{g} / \mathrm{ml}\right)$ 
The concentration of CANA was determined at $320 \mathrm{~nm}$ in MTF-CANA binary mixture in the corresponding $D_{1}$ curves obtained from the ratio spectra where the divisor was MTF $(18 \mu \mathrm{g} / \mathrm{ml})$. The concentration in the mixture was derived from the calibration curve of the $\mathrm{D}_{1} \mathrm{R}$ of standard CANA (fig. 10).
The concentration of GLIC was determined at $240 \mathrm{~nm}$ in MTF-GLIC binary mixture in the corresponding $\mathrm{D}_{1}$ curves obtained from the ratio spectra where the divisor was MTF $(18 \mu \mathrm{g} / \mathrm{ml})$. The concentration in the mixture was derived from the calibration curve of the $\mathrm{D}_{1} \mathrm{R}$ of standard GLIC (fig. 11).

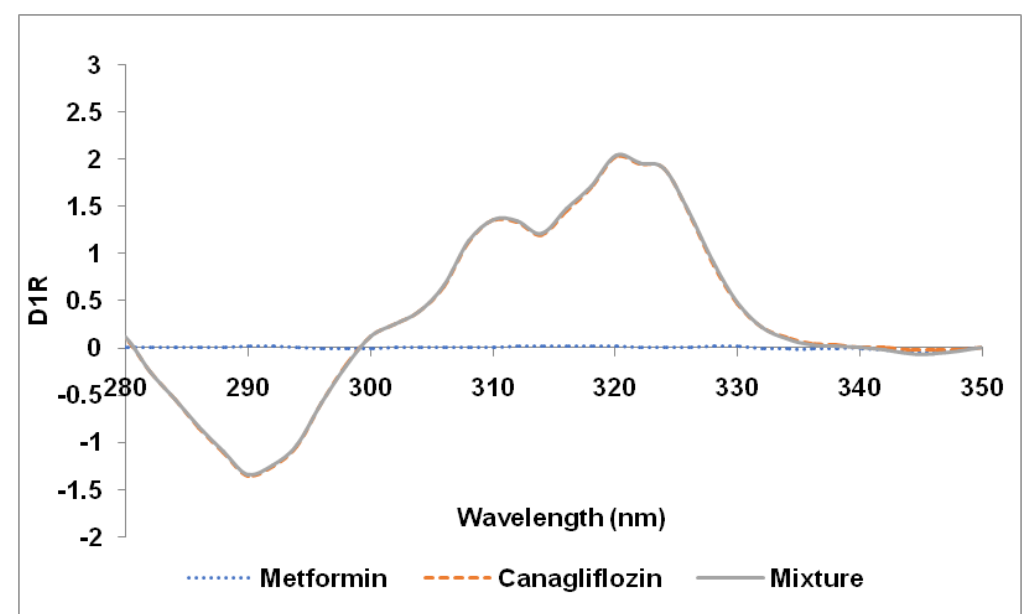

Fig. 10: $D_{1}$ of the ratio spectra of MTF $(16 \mu \mathrm{g} / \mathrm{ml})$, CANA $(5 \mu \mathrm{g} / \mathrm{ml})$ and their binary mixture where the divisor is $\mathrm{MTF}(18 \mu \mathrm{g} / \mathrm{ml})$

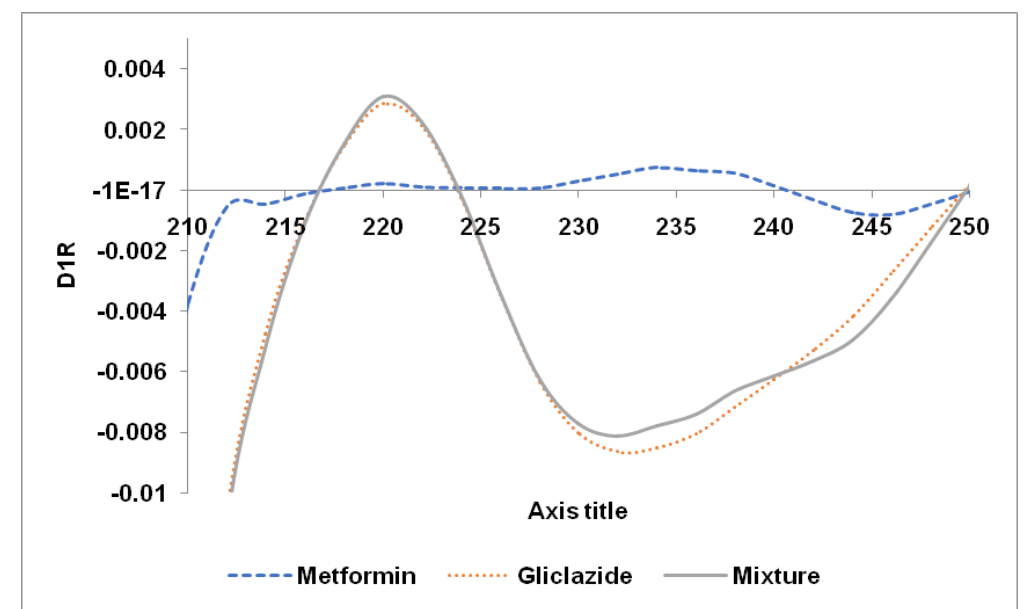

Fig. 11- $D_{1}$ of the Ratio spectra of MTF $(15 \mu \mathrm{g} / \mathrm{ml})$, GLIC $(3.5 \mu \mathrm{g} / \mathrm{ml})$ and their binary mixture where the divisor is $\mathrm{MTF}(18 \mu \mathrm{g} / \mathrm{ml})$

\section{Extended ratio subtraction method (EXRSM)}

The proposed method is based on that MTF has a more extended spectrum than CANA and GLIC as shown in fig. 2 and fig. 3.

This method begins by applying the Ratio subtraction method (RSM). It is done by dividing the zero order absorption spectra of the studied mixtures (A) by an absorption spectrum of carefully chosen concentration $\left(\mathrm{A}^{\circ}\right)$. Different concentrations of CANA and GLIC were tested, it was found that $2 \mu \mathrm{g} / \mathrm{ml}$ CANA or $4.5 \mu \mathrm{g} / \mathrm{ml}$ GLIC gave minimum noise, smoother ratio spectra and maximum sensitivity. Dividing the mixture absorption spectra by $2 \mu \mathrm{g} / \mathrm{ml}$ standard CANA or $4.5 \mu \mathrm{g} / \mathrm{ml}$ standard GLIC, produces new spectra, that represent $\left(\mathrm{A}_{\mathrm{CANA}} / \mathrm{A}_{\mathrm{CANA}}{ }^{\circ}+\mathrm{A}_{\mathrm{CANA}} / \mathrm{A}_{\mathrm{CANA}}{ }^{\circ}\right)$ or $\left(\mathrm{A}_{\mathrm{GLIC}} / \mathrm{A}_{\mathrm{GLIC}}{ }^{\circ}+\mathrm{A}_{\mathrm{MTF}} / \mathrm{A}_{\mathrm{GLIC}}{ }^{\circ}\right)$, where (Acana/Acana ${ }^{\circ}$ ) or (Aglic/Aglic ${ }^{\circ}$ ) have constant values. Then, subtraction of these constant values in the plateau region (270-300 $\mathrm{nm}$ ) in MTF-CANA binary mixture or (265-280 $\mathrm{nm}$ ) in MTF-GLIC binary mixture, followed by multiplication of the obtained spectra by the divisor spectrum, the original absorption spectrum of MTF is obtained and can be used directly for MTF determination at $237 \mathrm{~nm}$ from the corresponding regression equation $[27,34]$.

$\left(\mathrm{A}_{\mathrm{MTF}}+\mathrm{A}_{\mathrm{CANA}}\right) / \mathrm{A}_{\mathrm{CANA}}{ }^{\circ}$
$\mathrm{A}_{\mathrm{MTF}} / \mathrm{A}_{\mathrm{CANA}}{ }^{\circ}+\mathrm{A}_{\mathrm{CANA}} / \mathrm{A}_{\mathrm{CANA}}{ }^{\circ}=\mathrm{A}_{\mathrm{MTF}} / \mathrm{A}_{\mathrm{CANA}}{ }^{\circ}+$ constant.

$\mathrm{A}_{\mathrm{MTF}} / \mathrm{A}_{\mathrm{CANA}}{ }^{\circ}+$ constant-constant

$\mathrm{AmTF}_{\mathrm{M}} / \mathrm{AcAnA}^{\circ} * \mathrm{~A}_{\mathrm{CANA}}{ }^{\circ}$

$\mathrm{A}_{\mathrm{MTF}}$

$\left(\mathrm{A}_{\mathrm{MTF}}+\mathrm{A}_{\mathrm{GLIC}}\right) / \mathrm{A}_{\mathrm{GLIC}}{ }^{\circ}$

$\mathrm{A}_{\mathrm{MTF}} / \mathrm{A}_{\mathrm{GLIC}}{ }^{\circ}+\mathrm{A}_{\mathrm{GLIC}} / \mathrm{A}_{\mathrm{GLIC}}{ }^{\circ}=\mathrm{A}_{\mathrm{MTF}} / \mathrm{A}_{\mathrm{GLIC}}{ }^{\circ}+$ constant.

$\mathrm{A}_{\mathrm{MTF}} / \mathrm{AGLIC}^{\circ}+$ constant-constant

$\mathrm{A}_{\mathrm{MTF}} / \mathrm{A}_{\mathrm{GLIC}}{ }^{\circ *} \mathrm{~A}_{\mathrm{GLIC}}{ }^{\circ}$

$\mathrm{A}_{\mathrm{MTF}}$

The determination of CANA or GLIC could be done by the EXRSM. The spectrum of MTF obtained from the RSM method and the absorption spectra of the mixtures, are divided by the absorption spectrum of standard MTF having the concentration of $18 \mu \mathrm{g} / \mathrm{ml}$; producing a new spectrum that represents $\left(\mathrm{A}_{\mathrm{CANA}} / \mathrm{A}_{\mathrm{MTF}}{ }^{\circ}+\mathrm{A}_{\mathrm{CANA}} / \mathrm{A}_{\mathrm{MTF}}{ }^{\circ}\right)$ or $\left(\mathrm{A}_{\mathrm{GLIC}} / \mathrm{A}_{\mathrm{MTF}}\right.$ $\left.{ }^{\circ}+\mathrm{A}_{\mathrm{MTF}} / \mathrm{A}_{\mathrm{MTF}}{ }^{\circ}\right)$ and the constant $\left(\mathrm{A}_{\mathrm{MTF}} / \mathrm{A}_{\mathrm{MTF}}{ }^{\circ}\right)$ in the plateau region (210-250 nm). Subtracting the above produced constant spectrum 


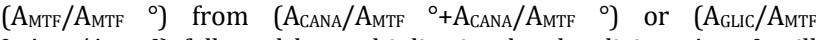
${ }^{\circ}+A_{\mathrm{MTF}} / \mathrm{A}_{\mathrm{MTF}}{ }^{\circ}$ ) followed by multiplication by the divisor $\mathrm{A}_{\mathrm{MET}}{ }^{\circ}$, will generate new spectra. These spectra could be used for the direct determination of CANA at $290 \mathrm{~nm}$ and GLIC at $228 \mathrm{~nm}$ and calculate their concentrations from the corresponding regression equation.

$\left(\mathrm{A}_{\mathrm{MTF}}+\mathrm{AcANA}_{\mathrm{C}}\right) / \mathrm{AmTF}^{\circ}$

$\mathrm{A}_{\mathrm{MTF}} / \mathrm{A}_{\mathrm{MTF}}{ }^{\circ}{ }_{+} \mathrm{A}_{\mathrm{CANA}} / \mathrm{A}_{\mathrm{MTF}}{ }^{\circ}=\mathrm{A}_{\mathrm{CANA}} / \mathrm{A}_{\mathrm{MTF}}{ }^{\circ}+$ constant.

$\mathrm{A}_{\mathrm{CANA}} / \mathrm{A}_{\mathrm{MTF}}{ }^{\circ}+$ constant-constant

$\mathrm{A}_{\mathrm{CANA}} / \mathrm{AmTF}^{\circ} * \mathrm{~A}_{\mathrm{MTF}}{ }^{\circ}$

Acana

$\left(\mathrm{A}_{\mathrm{MTF}}+\mathrm{A}_{\mathrm{GLIC}}\right) / \mathrm{A}_{\mathrm{MTF}}{ }^{\circ}$

$\mathrm{A}_{\mathrm{MTF}} / \mathrm{A}_{\mathrm{MTF}}{ }^{\circ}{ }_{+} \mathrm{A}_{\mathrm{GLIC}} / \mathrm{A}_{\mathrm{MTF}}{ }^{\circ}=\mathrm{A}_{\mathrm{GLIC}} / \mathrm{A}_{\mathrm{MTF}}{ }^{\circ}{ }_{+}$constant.

$\mathrm{A}_{\mathrm{GLIC}} / \mathrm{A}_{\mathrm{MTF}}{ }^{\circ}+$ constant-constant

$\mathrm{A}_{\mathrm{GLIC}} / \mathrm{A}_{\mathrm{MTF}}{ }^{\circ *} \mathrm{~A}_{\mathrm{MTF}}{ }^{\circ}$
Aglic

\section{RP-HPLC method}

RP-HPLC method was developed to provide an adequate method for the simultaneous determination of MTF-CANA and MTF-GLIC in the synthetic mixtures and in pharmaceutical formulations. The most important attribute is to achieve sufficient resolution with acceptable peak symmetry in a RP-HPLC method at reasonable time. So, preliminary investigations aimed to maximize the resolution and sensitivity of the method. The parameters were assessed and optimized as stated in Table 1.

Several mobile phases were tried using various ratios of different aqueous and organic modifiers. The best separation was obtained using a mobile phase composed of acetonitrile: phosphate buffer $(70: 30 \% \mathrm{v} / \mathrm{v})$ at $\mathrm{pH} 3$ with $0.01 \mathrm{M}$ sodium lauryl sulfate. Separation was done at wavelength of $229 \mathrm{~nm}$ and at a flow rate of $1 \mathrm{ml} / \mathrm{min}$. Fig. 12 and 13, show the separation of MTF at $3.9 \mathrm{~min}$, CANA at 9.1 min, and GLIC at $6.9 \mathrm{~min}$.

Table 1: Optimized chromatographic conditions for the separation of MTF-CANA and MTF-GLIC

\begin{tabular}{ll}
\hline Parameter & Condition \\
\hline Mobile Phase & Acetonitrile: phosphate buffer $(70: 30)$ at $\mathrm{pH}$ 3 with 0.01 M sodium lauryl sulfate \\
Stationary Phase & C18 column $(250 \mathrm{~mm} \times 4.6 \mathrm{~mm} \times 5 \mu \mathrm{m})$ \\
Flow rate $(\mathrm{ml} / \mathrm{min})$ & 1 \\
Run time $(\mathrm{min})$ & 10 \\
Volume of injection $(\mu \mathrm{l})$ & 20 \\
Detection wavelength $(\mathrm{nm})$ & 229 \\
\hline
\end{tabular}

Table 2: HPLC system suitability parameters for the determination of MTF-CANA and MTF-GLIC using the proposed method

\begin{tabular}{llllll}
\hline & $\begin{array}{l}\text { Retention time } \\
\mathbf{t}_{\mathbf{R}}\end{array}$ & $\begin{array}{l}\text { Capacity factor } \\
\mathbf{k}^{\prime}\end{array}$ & $\begin{array}{l}\text { Resolution } \\
\mathbf{R}_{\mathbf{s}}\end{array}$ & $\begin{array}{l}\text { Column efficiency } \\
\mathbf{N}\end{array}$ & $\begin{array}{l}\text { Tailing factor } \\
\mathbf{T}\end{array}$ \\
\hline Metformin & 3.92 & 1.04 & --- & 2230 & 1.407 \\
Canagliflozin & 6.917 & 2.60 & 5.5 & 3265 & 1.303 \\
Gliclazide & 9.10 & 3.74 & 12.3 & 3702 & 2.5 \\
\hline
\end{tabular}

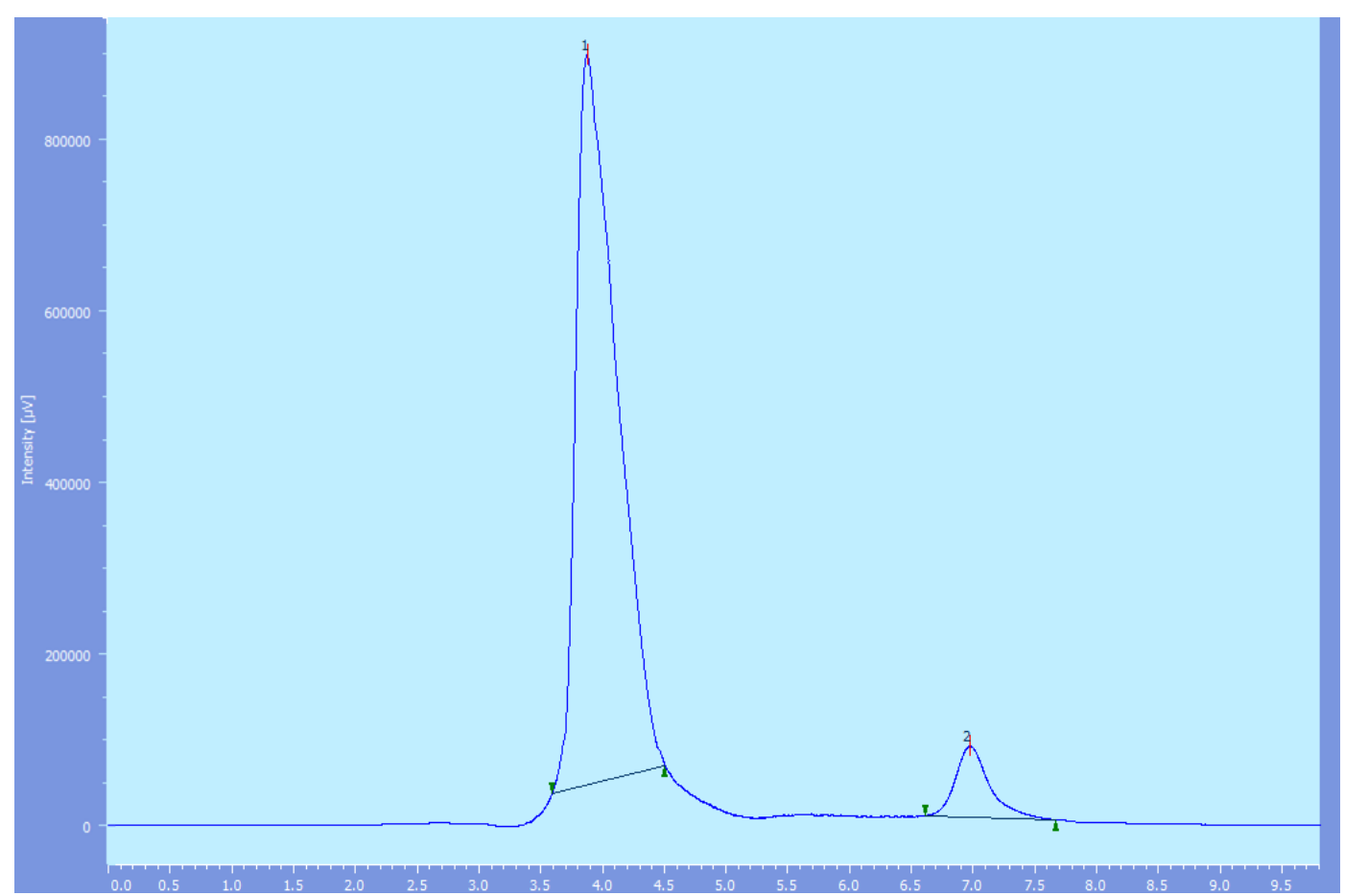

Fig. 12: HPLC chromatogram of a $20 \mu \mathrm{l}$ injection of a standard mixture of $250 \mu \mathrm{g} / \mathrm{ml}$ MTF and $50 \mu \mathrm{g} / \mathrm{ml}$ CANA using the optimized chromatographic conditions 


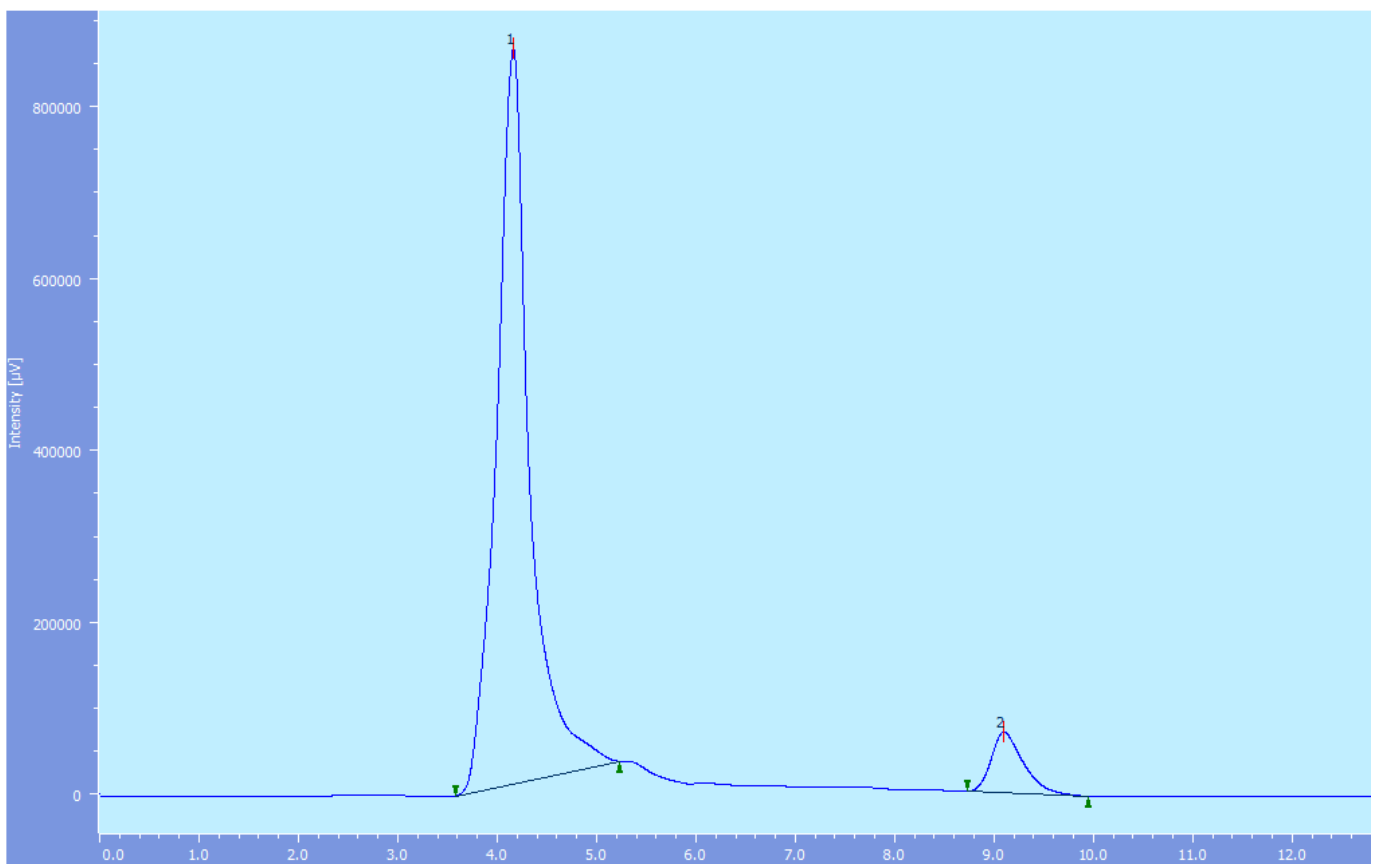

Fig. 13: HPLC chromatogram of a $20 \mu \mathrm{l}$ injection of a standard mixture of $250 \mu \mathrm{g} / \mathrm{ml} \mathrm{MTF}$ and $40 \mu \mathrm{g} / \mathrm{ml} \mathrm{GLIC} \mathrm{using} \mathrm{the} \mathrm{optimized}$ chromatographic conditions

Table 3: Assay parameters for the determination of MTF-CANA and MTF-GLIC in presence of each other using the applied spectrophotometric methods

\begin{tabular}{|c|c|c|c|c|c|c|}
\hline \multicolumn{7}{|l|}{ Metformin } \\
\hline Parameters & $\mathbf{A}$ & & $\Delta \mathbf{P}$ & & $\mathbf{D}_{1} \mathbf{R}$ & \\
\hline Conc. Range $(\mu \mathrm{g} / \mathrm{ml})$ & $2.0-20.0$ & & & & & \\
\hline$\lambda$ or $\lambda_{\text {range }(\mathrm{nm})}$ & 237 & 228 & $248-222$ & $233-211$ & 244 & 244 \\
\hline$\Delta \lambda_{(\mathrm{nm})}$ & & & & & 6 & 8 \\
\hline $\mathrm{r}$ & 0.9993 & 0.9993 & 0.9993 & 0.9994 & 0.9996 & 0.9989 \\
\hline$S_{y / x}$ & 0.0149 & 0.0119 & 0.29543 & 2.68213 & 0.02027 & 0.23625 \\
\hline a (intercept) & 0.0262 & -0.002 & 0.19663 & 1.14748 & 0.02569 & -0.16933 \\
\hline b (slope) & 0.0905 & 0.0687 & 2.13804 & 15.4521 & 0.18266 & -1.02883 \\
\hline $\mathrm{S}_{\mathrm{a}}$ & 0.0103 & 0.0083 & 0.31418 & 1.65844 & 0.02156 & 0.13769 \\
\hline$S_{b}$ & 0.0008 & 0.0007 & 0.02279 & 0.13509 & 0.00156 & 0.01162 \\
\hline $\mathrm{LOD}(\mu \mathrm{g} / \mathrm{ml})$ & 0.54 & 0.57 & 0.46 & 0.57 & 0.37 & 0.76 \\
\hline $\mathrm{LOQ}(\mu \mathrm{g} / \mathrm{ml})$ & 1.65 & 1.73 & 1.38 & 1.74 & 1.11 & 2.30 \\
\hline \multicolumn{7}{|l|}{ Gliclazide } \\
\hline Parameters & $\mathbf{A}$ & & $\Delta \mathbf{P}$ & & & \\
\hline Conc. Range $(\mu \mathrm{g} / \mathrm{ml})$ & $2.0-30.0$ & & & & & \\
\hline$\lambda$ or $\lambda$ range(nm) & 228 & 237 & $223-248$ & & 240 & \\
\hline \multicolumn{7}{|l|}{$\Delta \lambda_{(\mathrm{nm})}$} \\
\hline $\mathrm{r}$ & 0.9998 & 0.9983 & 0.9997 & & 0.9996 & \\
\hline$S_{y / x}$ & 0.00732 & 0.00407 & 0.00711 & & 0.00046 & \\
\hline a (intercept) & -0.00717 & -0.00537 & -0.00092 & & 0.00069 & \\
\hline b (slope) & 0.04354 & 0.02551 & 0.03703 & & -0.00204 & \\
\hline $\mathrm{S}_{\mathrm{a}}$ & 0.00456 & 0.00253 & 0.00381 & & 0.00025 & \\
\hline $\mathrm{S}_{\mathrm{b}}$ & 0.00027 & 0.00015 & 0.00024 & & 0.00002 & \\
\hline $\mathrm{LOD}(\mu \mathrm{g} / \mathrm{ml})$ & 0.55 & 0.53 & 0.63 & & 0.75 & \\
\hline $\mathrm{LOQ}(\mu \mathrm{g} / \mathrm{ml})$ & 1.68 & 1.60 & 1.92 & & 2.28 & \\
\hline \multicolumn{7}{|l|}{ Canagliflozin } \\
\hline Parameters & $\mathbf{A}$ & & $\Delta \mathbf{P}$ & & $\mathbf{D}_{1} \mathbf{R}$ & \\
\hline Conc. Range $(\mu \mathrm{g} / \mathrm{ml})$ & $1.5-40.0$ & & & & & \\
\hline$\lambda$ or $\lambda$ range(nm) & 290 & 237 & $278-295$ & & 320 & \\
\hline$\Delta \lambda_{(\mathrm{nm})}$ & & & & & 8 & \\
\hline $\mathrm{r}$ & 0.9999 & 0.9987 & 0.9998 & & 0.9999 & \\
\hline$S_{y / x}$ & 0.00560 & 0.00564 & 0.71436 & & 0.01384 & \\
\hline a (intercept) & 0.00169 & -0.00858 & -0.70414 & & 0.02059 & \\
\hline b (slope) & 0.04180 & 0.00958 & -2.96632 & & 0.36026 & \\
\hline $\mathrm{S}_{\mathrm{a}}$ & 0.00317 & 0.00320 & 0.31916 & & 0.00618 & \\
\hline$S_{b}$ & 0.00015 & 0.00015 & 0.01739 & & 0.00034 & \\
\hline $\mathrm{LOD}(\mu \mathrm{g} / \mathrm{ml})$ & 0.44 & 1.94 & 0.79 & & 0.13 & \\
\hline $\mathrm{LOQ}(\mu \mathrm{g} / \mathrm{ml})$ & 1.34 & 5.89 & 2.41 & & 0.38 & \\
\hline
\end{tabular}


Table 4: Assay parameters for the determination of MTF, GLIC and CANA using the proposed RP-HPLC method

\begin{tabular}{|c|c|c|c|}
\hline Parameter & MTF & GLIC & CANA \\
\hline Concentration range $(\mu \mathrm{g} / \mathrm{ml})$ & $50-300$ & $10-100$ & $5-50$ \\
\hline \multicolumn{4}{|l|}{ Regression equation } \\
\hline Intercept (a) & -1680665.31 & -102139 & 44163.13 \\
\hline Slope (b) & 99378.45 & 39954.37 & 15229.25 \\
\hline Correlation coefficient (r) & 0.998 & 0.999 & 0.999 \\
\hline $\mathrm{S}_{\mathrm{a}}$ & 459559.95 & 33158.89 & 1645.24 \\
\hline $\mathrm{S}_{\mathrm{b}}$ & 2360.08 & 484.32 & 55.82 \\
\hline $\mathrm{S}_{\mathrm{y} / \mathrm{x}}$ & 493646.57 & 27074.12 & 1966.22 \\
\hline $\operatorname{LOD}(\mu \mathrm{g} / \mathrm{ml})$ & 16.39 & 2.24 & 0.43 \\
\hline $\mathrm{LOQ}(\mu \mathrm{g} / \mathrm{ml})$ & 49.67 & 6.78 & 1.29 \\
\hline
\end{tabular}

\section{System suitability}

In accordance to Food and Drug Administration (FDA) guidance, system suitability tests are of the essentials in any liquid chromatographic method [36]. Under the optimized chromatographic conditions, system suitability parameters including capacity factor $\left(k^{\prime}\right)$, resolution $\left(R_{s}\right)$, column efficiency $(N)$, tailing factor $(\mathrm{T})$, repeatability in terms of Relative Standard Deviation (RSD), and selectivity ( $\alpha$ ) were performed and listed in table 2. All were satisfactory pointing out the selectivity and efficiency of the method for separation of the binary mixtures MTFCANA and MTF-GLIC.

\section{Method validation}

Under the optimized experimental conditions, the developed methods were validated according to the procedures described in ICH guidelines [35].

Linearity, concentration range, limit of detection and limit of quantitation

Under the described experimental conditions, linearity was established over the concentration ranges stated in Tables 3 and 4; the graphs were obtained by plotting the ratio difference $(\Delta \mathrm{P})$, and $D_{1}$ of the ratio spectra or the peak area each versus concentration of MTF, CANA or GLIC in case of chemometric methods and RP-HPLC method, respectively.

The values of the correlation coefficient ( $r$ ), intercept (a), slope (b) and standard deviation of residuals $\left(S_{y / x}\right)$ showed good linearity of the calibration graphs and the conformity with Beer's law. The low LOD and $L O Q$ values obtained confirm the sensitivity of the proposed methods (tables 3 and 4).

\section{Accuracy and precision}

The percentage recoveries were obtained for each mixture by applying the $\triangle \mathrm{P}, \mathrm{D}_{1} \mathrm{R}, \mathrm{RSM}$ and RP-HPLC methods (Tables 5, 6 and 7). The spectral interferences in the determination of MTF-CANA or MTF-GLIC in the presence of each other using the proposed methods were corrected. Good percentage recoveries were obtained. These applied methods indicate their potential for correction of spectral interferences in the determination of MTF-CANA and MTF-GLIC binary mixtures.

Table 5: Intra-day and inter-day precision for the simultaneous determination of MTF-CANA, and MTF-GLIC in presence of each other in synthetic mixture using the proposed spectrophotometric methods

\begin{tabular}{|c|c|c|c|c|c|}
\hline \multirow[t]{2}{*}{ Analytical Method } & \multirow[t]{2}{*}{$\begin{array}{l}\text { MTF: GLIC } \\
\mu \mathrm{g} / \mathrm{ml}\end{array}$} & \multicolumn{2}{|c|}{$\begin{array}{l}\text { Intra-day precision, mean recovery } \pm \text { SD } \\
\% R S D, \% \text { error }\end{array}$} & \multicolumn{2}{|c|}{$\begin{array}{l}\text { Inter-day precision, mean recovery } \pm \text { SD } \\
\% R S D, \% \text { error }\end{array}$} \\
\hline & & MTF & GLIC & MTF & GLIC \\
\hline \multirow[t]{3}{*}{$\Delta \mathrm{P}$} & $15: 2.5$ & $99.32 \pm 1.15$ & $98.99 \pm 0.37$ & $99.10 \pm 1.44$ & $99.04 \pm 4.47$ \\
\hline & & 1.16 & 0.38 & 1.45 & 4.52 \\
\hline & & 0.68 & 1.01 & 0.90 & 0.96 \\
\hline \multirow[t]{3}{*}{$\mathrm{D}_{1} \mathrm{R}$} & $15: 2.5$ & $99.51 \pm 0.88$ & $100.39 \pm 0.35$ & $99.34 \pm 1.14$ & $100.39 \pm 1.21$ \\
\hline & & 0.88 & 0.35 & 1.15 & 1.20 \\
\hline & & 0.49 & -0.39 & 0.66 & -0.39 \\
\hline \multirow[t]{3}{*}{ RSM } & $15: 2.5$ & $99.57 \pm 0.29$ & $100.38 \pm 0.75$ & $99.51 \pm 1.94$ & $100.57 \pm 2.19$ \\
\hline & & 0.30 & 0.75 & 1.95 & 2.18 \\
\hline & & 0.43 & -0.38 & 0.49 & -0.57 \\
\hline \multirow[t]{2}{*}{ Analytical Method } & $\begin{array}{l}\text { MTF: CANA } \\
\mu \mathrm{g} / \mathrm{ml}\end{array}$ & \multicolumn{2}{|c|}{$\begin{array}{l}\text { Intra-day precision, mean recovery } \pm \text { SD } \\
\% R S D, \% \text { error }\end{array}$} & \multicolumn{2}{|c|}{$\begin{array}{l}\text { Inter-day precision, mean recovery } \pm \text { SD } \\
\% \mathrm{RSD}, \% \text { error }\end{array}$} \\
\hline & & MTF & CANA & MTF & CANA \\
\hline \multirow[t]{3}{*}{$\Delta \mathrm{P}$} & $20: 5$ & $101.28 \pm 0.07$ & $100.73 \pm 1.87$ & $101.35 \pm 0.31$ & $99.34 \pm 2.12$ \\
\hline & & 0.07 & 1.86 & 0.31 & 2.13 \\
\hline & & -1.28 & -0.73 & -1.35 & 0.66 \\
\hline \multirow[t]{3}{*}{ D1R } & $20: 5$ & $100.03 \pm 0.29$ & $100.95 \pm 1.01$ & $100.34 \pm 0.45$ & $101.32 \pm 1.65$ \\
\hline & & 0.29 & 1.00 & 0.45 & 1.63 \\
\hline & & -0.03 & -0.95 & -0.34 & -1.32 \\
\hline \multirow[t]{3}{*}{ RSM } & $20: 5$ & $100.77 \pm 0.11$ & $104.65 \pm 1.71$ & $100.88 \pm 0.36$ & $103.06 \pm 2.08$ \\
\hline & & 0.11 & 1.63 & 0.36 & 2.01 \\
\hline & & -0.77 & -4.65 & -0.88 & -3.06 \\
\hline
\end{tabular}

mean \pm SD for five determinations, Relative standard deviation, Relative error

\section{Method application}

The validated spectrophotometric chemometric and RP-HPLC methods were successfully applied for the determination of the binary mixtures MTF-CANA and MTF-GLIC in their pharmaceutical formulations Orbizide ${ }^{\circledR}$ and Vokanamet ${ }^{\circledR}$. High percentage recoveries were obtained with low \% RSD which indicate high accuracy and precision in the determination of the studied mixtures in their commercial tablets without the interference of the common excipients in the determination. The results obtained are summarized in table 8 and compared statistically by means of Student's t-test for accuracy and F-test for precision at 95\% confidence level. 
Table 6: System accuracy and precision data for the determination of MTF, GLIC and CANA using the proposed RP-HPLC method

\begin{tabular}{|c|c|c|c|c|c|}
\hline & $t_{R}$ & Amount taken $(\mu \mathrm{g} / \mathrm{ml})$ & Amount found $(\mu \mathrm{g} / \mathrm{ml})$ & a\% RSD & b\% Recovery \\
\hline \multirow{3}{*}{ MTF } & $3.92 \pm 0.02$ & 100 & 98.82 & 1.24 & 98.82 \\
\hline & & 200 & 198.46 & 1.07 & 99.23 \\
\hline & & 250 & 245.38 & 0.44 & 98.15 \\
\hline \multirow[t]{3}{*}{ GLIC } & $9.10 \pm 0.33$ & 25 & 25.05 & 1.22 & 100.20 \\
\hline & & 40 & 40.03 & 0.90 & 100.07 \\
\hline & & 100 & 100.42 & 0.40 & 100.42 \\
\hline \multirow[t]{3}{*}{ CANA } & $6.917 \pm 0.12$ & 5 & 4.93 & 1.33 & 98.60 \\
\hline & & 10 & 10.12 & 1.1 & 101.20 \\
\hline & & 50 & 49.99 & 1.73 & 99.98 \\
\hline
\end{tabular}

aRelative standard deviation, ${ }^{\mathrm{b}}$ Mean for five determinations

Table 7: Accuracy and precision data for the simultaneous determination of MTF-GLIC and MTF-CANA in synthetic mixtures using the proposed RP-HPLC method

\begin{tabular}{|c|c|c|c|c|c|c|}
\hline \multirow[t]{2}{*}{ Mixture } & \multirow{2}{*}{\multicolumn{2}{|c|}{ Nominal value $(\mu \mathrm{g} / \mathrm{ml})$}} & \multicolumn{4}{|c|}{ Statistic parameters, ${ }^{\mathrm{a}}$ Mean recovery \pm SD, $\mathrm{b} \% \mathrm{RSD}, \mathrm{c} \%$ Error } \\
\hline & & & \multicolumn{2}{|c|}{ Inter-day } & \multicolumn{2}{|c|}{ Intra-day } \\
\hline \multirow[t]{10}{*}{ MTF: GLIC } & MTF & GLIC & MTF & GLIC & MTF & GLIC \\
\hline & 250 & 15 & $100.36 \pm 1.91$ & $101.53 \pm 0.31$ & $99.01 \pm 1.09$ & $101.31 \pm 0.99$ \\
\hline & & & 1.90 & 0.31 & 1.10 & 0.98 \\
\hline & & & 0.36 & 1.53 & 0.99 & 1.31 \\
\hline & 250 & 30 & $101.10 \pm 1.64$ & $99.64 \pm 0.12$ & $99.94 \pm 1.95$ & $99.72 \pm 1.68$ \\
\hline & & & 1.62 & 0.12 & 1.96 & 1.68 \\
\hline & & & 1.10 & 0.35 & 0.06 & 0.28 \\
\hline & 250 & 40 & $101.76 \pm 1.05$ & $100.82 \pm 1.69$ & $101.05 \pm 1.09$ & $99.62 \pm 1.88$ \\
\hline & & & 0.99 & 1.68 & 1.08 & 1.89 \\
\hline & & & 1.76 & 0.82 & 1.05 & 0.38 \\
\hline \multirow[t]{10}{*}{ MTF: CANA } & MTF & CANA & MTF & CANA & MTF & CANA \\
\hline & 250 & 10 & $99.58 \pm 1.09$ & $99.59 \pm 1.37$ & $100.36 \pm 1.73$ & $100.57 \pm 1.68$ \\
\hline & & & 1.10 & 1.38 & 1.72 & 1.67 \\
\hline & & & 0.42 & 0.41 & 0.36 & 0.57 \\
\hline & 250 & 15 & $99.76 \pm 0.18$ & $100.53 \pm 0.41$ & $99.63 \pm 0.61$ & $100.24 \pm 0.79$ \\
\hline & & & 0.18 & 0.41 & 0.61 & 0.79 \\
\hline & & & 0.24 & 0.53 & 0.37 & 0.24 \\
\hline & 250 & 45 & $100.52 \pm 0.34$ & $99.96 \pm 0.60$ & $100.28 \pm 0.36$ & $99.54 \pm 0.89$ \\
\hline & & & 0.34 & 0.60 & 0.36 & 0.90 \\
\hline & & & 0.52 & 0.04 & 0.28 & 0.46 \\
\hline
\end{tabular}

${ }^{a}$ mean \pm SD for three determinations, ${ }^{b}$ Relative standard deviation, ${ }^{c}$ Relative error

Table 8: Assay results for MTF-GLIC, and MTF-CANA in commercial tablets using the proposed spectrophotometric methods

\begin{tabular}{|c|c|c|c|c|c|}
\hline & \multirow{2}{*}{$\begin{array}{l}\text { Drug } \\
\text { Analytical method }\end{array}$} & \multicolumn{4}{|c|}{ aMean recovery \pm SD, b\%RSD, c\%Error } \\
\hline & & $\Delta \mathbf{P}$ & $\mathbf{D}_{1} \mathbf{R}$ & RSM & HPLC reference method \\
\hline \multirow[t]{10}{*}{ Orbizide ${ }^{\circledR}$} & MTF & $99.30 \pm 2.02$ & $99.02 \pm 0.83$ & $99.46 \pm 1.43$ & $100.47 \pm 1.41$ \\
\hline & $* *$ t-test & 2.04 & 0.84 & 1.44 & 1.40 \\
\hline & $* *$ F-test & 0.70 & 0.98 & 0.54 & 0.47 \\
\hline & & 0.234635 & 0.221213 & 0.224255 & \\
\hline & & 0.498552 & 0.331214 & 0.974474 & \\
\hline & GLIC & $100.70 \pm 3.56$ & $100.52 \pm 1.24$ & $98.49 \pm 0.32$ & $100.02 \pm 2.27$ \\
\hline & $* *$ t-test & 3.54 & 1.23 & 0.33 & 2.27 \\
\hline & ${ }^{* *} \mathrm{~F}$-test & -0.70 & -0.52 & 1.51 & 0.02 \\
\hline & & 0.349676 & 0.325684 & 0.104272 & \\
\hline & & 0.404388 & 0.606591 & 0.002343 & \\
\hline \multirow[t]{10}{*}{ Vokanamet ${ }^{\circledR}$} & MTF & $99.18 \pm 0.20$ & $99.17 \pm 0.22$ & $99.76 \pm 0.25$ & $100.01 \pm 0.06$ \\
\hline & $* *$ t-test & 0.20 & 0.22 & 0.25 & 0.06 \\
\hline & ${ }^{* *} \mathrm{~F}$-test & 0.82 & 0.83 & 0.24 & 0.01 \\
\hline & & 0.000823 & 0.001533 & 0.030061 & \\
\hline & & 0.074935 & 0.055256 & 0.03903 & \\
\hline & CANA & $99.70 \pm 1.71$ & $99.62 \pm 1.12$ & $101.16 \pm 1.38$ & $98.36 \pm 0.66$ \\
\hline & $* *$ t-test & 1.71 & 1.12 & 1.37 & 0.67 \\
\hline & $* *$ F-test & 0.30 & 0.38 & -1.16 & 1.64 \\
\hline & & 0.126203 & 0.02773 & 0.015041 & \\
\hline & & 0.092205 & 0.328933 & 0.180202 & \\
\hline
\end{tabular}

amean \pm SD for five determinations, belative standard deviation, cRelative error, ${ }^{* *}$ Theoretical values of $\mathrm{t}$-and $\mathrm{F}$-test at $\mathrm{P}=0.05$ are 2.13 and 5.05 respectively

\section{CONCLUSION}

In conclusion, the present work represents an approach for the assay of the MTF-CANA and MTF-GLIC antidiabetic binary mixtures.
The developed chemometric methods depend on the absorption spectra of the drugs. The use of ratio spectra can magnify the prediction ability of the usual spectrophotometric techniques, where the treatment of absorbance ratio generates signals for the mixtures 
depending only on one analyte and eliminating the interfering effect of other analytes in the mixture. Such methods are considered as highly sensitive, low cost green analytical techniques, where most of the work is done in front of the computer, thus it applies neither sophisticated instrument nor prior separation steps. Accordingly, such methods can be employed for the quality control of these drugs in pharmaceutical companies. Although the developed RP-HPLC is not more sensitive than the applied chemometric methods, but it can give an advantage for future plans for the analysis of the same mixtures in biological fluids.

\section{FUNDING}

Nil

\section{AUTHORS CONTRIBUTIONS}

Malak Y. Al Bathish designed and performed the experiments and the measurements. Azza A. Gazy was involved in planning and supervised the work. Malak Y. Al Bathish and Azza A. Gazy processed the experimental data along with the calculations, designed the fig. and interpreted the results. Malak Y. Al Bathish, Azza A. Gazy and Marwa K. El Jamal revised the results and drafted the manuscript.

\section{CONFLICTS OF INTERESTS}

The authors declare that there are no conflicts of interest.

\section{REFERENCES}

1. World Health Organization. Global Report on Diabetes. World Helath Organisation Global report on diabetes; 2016.

2. British Pharmacopoeia Commission. British pharmacopoeia, 1932. Analyst 1933;58:697.

3. USP US. Pharmacopoeia-national formulary [USP $38 \mathrm{NF}$ 33]. Rockville, Md United States Pharmacopeial Conv; 2015.

4. Panigrahy U, Reddy A. A novel validated RP-HPLC-DAD method for the simultaneous estimation of metformin hydrochloride and canagliflozin in bulk and pharmaceutical tablet dosage form with forced degradation studies. Orient J Chem 2015;3:1489-507.

5. Reddy NP, Chevela NT. RP-HPLC method development and validation for the simultaneous estimation of metformin and canagliflozin in tablet dosage form. Int J Pharma Sci 2015;5:1155-9.

6. Gaware D, Patil RN, Harole M. A validated stability indicating RP-HPLC method for simultaneous determination of metformin and canagliflozin in pharmaceutical formulation. World J Pharm Pharm Sci 2015; 4:631-40.

7. Sai VM, Guptha DV, Krishna BSM, Vasantharaju SG. Stability indicating assay method development and validation of naratriptan hydrochloride by RP-HPLC. Res J Pharm Technol 2016;9:1177.

8. Lotfy HM, Mohamed D, Elshahed MS. Different mathematical processing of absorption, ratio and derivative spectra for quantification of mixtures containing minor component: an application to the analysis of the recently co-formulated antidiabetic drugs; canagliflozin and metformin. Spectrochim Acta Part A Mol Biomol Spectrosc 2018;189:100-9.

9. Havele SS, Dhaneshwar SR. Simultaneous determination of metformin hydrochloride in its multicomponent dosage forms with sulfonyl ureas like gliclazide and glimepiride using HPTLC. J Liq Chromatogr Relat Technol 2011;34:966-80.

10. Patil V, Kale S, Sahare P, Vithaldas S. Simultaneous HPTLC analysis of gliclazide and metformin hydrochloride in bulk and tablet dosage form. J Sci Innov Res 2014;3:325-31.

11. Zhong G, Bi H, Zhou S, Chen X, Huang M. Simultaneous determination of metformin and gliclazide in human plasma by liquid chromatography-tandem mass spectrometry: application to a bioequivalence study of two formulations in healthy volunteers. J Mass Spectrom 2005;40:1462-71.

12. Agrawal Y, Gogoi P, Manna K, Bhatt H, Jain V. A supercritical fluid chromatography/tandem mass spectrometry method for the simultaneous quantification of metformin and gliclazide in human plasma. Indian J Pharm Sci. 2010;72:50.

13. Loni AB, Ghante MR, Sawant SD. Simultaneous UV spectrophotometric method for estimation of sitagliptin phosphate and metformin hydrochloride in bulk and tablet dosage form. Der Pharma Chem 2012;4:854-9.

14. Bhaskar R, Bhaskar R, K Sagar M. UV-spectrophotometricassisted chemometric methods for the simultaneous determination of metformin hydrochloride and gliclazide in pharmaceutical formulations. Pharm Anal Acta 2012;3. Doi:10.4172/2153-2435.1000158

15. Bhaskar R, Bhaskar R, Sagar MK, Saini V. Multivariate chemometric assisted analysis of metformin hydrochloride, gliclazide and pioglitazone hydrochloride in bulk drug and dosage forms. Adv Pharm Bull 2013;3:79-84.

16. Chopade JR, Deshpande SV, Shah S. Simultaneous estimation of metformin $\mathrm{HCl}$ and gliclazide by q-analysis method. Int J Pharm Res Sch 2013;2:66-73.

17. Moosasalam B, Kanaka Narasimhaiah T KVL. A new validated uv spectrophotometric method for the simultaneous estimation of metformin hydrochloride and gliclazide in combined tablet dosage form by dual wavelength method. Inven Rapid Pharm Anal Qual Assur; 2014. p. 1-6.

18. Havele S, Dhaneshwar S. Development and validation of a hplc method for the determination of metformin hydrochloride, gliclazide and piogliglitazone hydrochloride in multicomponent formulation. Webmed Central Pharm Sci; 2010. p. 1.

19. Rao U. Determination of gliclazide in a tablet dosage form in the presence of metformin hydrochloride by ion pair reversed phase liquid chromatographic technique. African J Pharm Pharmacol 2011;5:1331-7.

20. Vadnere BV. RP-HPLC method for simultaneous estimation of gliclazide and metformin in their dosage form. J Pharm Res 2012;5:5036-8.

21. Sasi E, Goud K, Reddy VK, Sekhar CK. A new simple RP-HPLC method for simultaneous estimation of metformin HCL and gliclazide tablet dosage form. Int J Pharm Biol Sci 2012;2:277-83.

22. Akula A, Prajwala N, Sandhya M, Maheswara Rao U. Development and validation of RP-HPLC method for simultaneous estimation of metformin hydrochloride and gliclazide in bulk and combined doasage form. Int J Pharm Pharm Sci 2013;5:511-7.

23. Elkady E, El-Zaher A, Elwy H Mohamed, Saleh M. Validated liquid chromatographic method for simultaneous determination of metformin, pioglitazone, sitagliptin, repaglinide, glibenclamide and gliclazide-application for counterfeit drug analysis. J Anal Bioanal Tech 2015;6. Doi:10.4172/2155-9872.

24. Nirupama D, Rao PV, Thangabalan B, Manohar Babu S. Method development and validation for metformin hydrochloride and gliclazide in bulk and pharmaceutical formulation by rp-hplc method. Int J Innov Pharm Sci Res 2014;2:1428-37.

25. Pawar J, Sonawane S, Chhajed S, Kshirsagar S. Development and validation of RP-HPLC method for simultaneous estimation of metformin HCl and gliclazide. Asian J Pharm Anal 2016;6:151-4.

26. Nirupama D, Venkateswara Rao P, Thangabalan B MBP. Development and validation of RP-HPLC method for simultaneous estimation of gliclazide and metformin in pure and tablet dosage form. Int J Pharm Anal Res 2014;3:326-33.

27. Amira $\mathrm{H}$ Kamal, SFE-M and SFH. A review on UV spectrophotometric methods for simultaneous multicomponent analysis. Eur J Pharm Med Res 2016;3:348-60.

28. El Jamal MK, Gazy AA. Analysis of three cardiovascular drugs in their ternary mixture using green analytical methodology of smart spectrophotometric methods and RP-HPLC method. Int J Pharm Pharm Sci 2016;8:243-50.

29. Belal TS, Daabees HG, Abdel-Khalek MM, Mahrous MS, Khamis MM. New simple spectrophotometric method for determination of the binary mixtures (atorvastatin calcium and ezetimibe; candesartan cilexetil and hydrochlorothiazide) in tablets. J Pharm Anal 2013;3:118-26.

30. Salinas F. A new spectrophotometric method for quantitative multicomponent analysis resolution of mixtures of salicylic and salicyluric acids. Talanta 1990;37:347-51.

31. Bhatt NM, Chavada VD, Sanyal M, Shrivastav PS. Manipulating ratio spectra for the spectrophotometric analysis of diclofenac sodium and pantoprazole sodium in laboratory mixtures and tablet formulation. Sci World J 2014:1-10. http://dx.doi.org/ 10.1155/2014/495739. 
32. Lotfy HM, Abdel Monem Hagazy M. Comparative study of novel spectrophotometric methods manipulating ratio spectra: an application on pharmaceutical ternary mixture of omeprazole, tinidazole and clarithromycin. Spectrochim Acta Part A Mol Biomol Spectrosc 2012;96:259-70.

33. El-Bardicy MG, Lotfy HM, El-Sayed MA, El-Tarras MF. Smart stability-indicating spectrophotometric methods for determination of binary mixtures without prior separation. J AOAC Int 2008;91:299-310.
34. El-Malla S. Simultaneous determination of tapentadol $\mathrm{HCl}$ and paracetamol by ratio-spectra derivative spectrophotometry. World J Pharm Sci 2015;3:1290-7.

35. ICH. Validation of analytical procedures: text and methodology Q2(R1). International Conference on Harmonization of Techinical Requirements for Registration of Pharmaceuticals for Human Use; 2005.

36. Analytical Methods Technical Commitee. Validation of chromatographic methods. Cent drug Eval Res Food Drug Adm; 1994. 